\title{
Profiling and distribution of minerals content in cow, buffalo and goat milk
}

\author{
Manju Singh, Rajan Sharma, Suvartan Ranvir, Kamal Gandhi and Bimlesh Mann
}

Received: 04 March 2019 / Accepted: 05 July 2019 / Published online: 28 October 2019

(C) Indian Dairy Association (India) 2019

\begin{abstract}
Nine minerals (calcium $(\mathrm{Ca})$, magnesium $(\mathrm{Mg})$, sodium $(\mathrm{Na})$, potassium $(\mathrm{K})$, phosphorus $(\mathrm{P})$, zinc $(\mathrm{Zn})$, iron $(\mathrm{Fe})$, copper $(\mathrm{Cu})$ and manganese $(\mathrm{Mn})$ ) have been estimated in milk of three different species namely, cow (Sahiwal and Tharparkar), buffalo (Murrah) and goat (Alpine x Beetle) of India. Among the species studied, buffalo milk had the highest $\mathrm{Ca}, \mathrm{P}$ and $\mathrm{Mg}$ contents. $\mathrm{Na}$ content was found lowest in buffalo milk and $\mathrm{K}$ was found significantly higher in goat milk. K was the major mineral in cow and goat milk while Ca was major mineral in buffalo milk. Mineral distribution data indicated that colloidal minerals were highest in buffalo milk followed by goat and cow milk. Ca to $\mathrm{P}$ ratio was found maximum in buffalo milk (1.74) and was almost similar in milk (1.45-1.49) of other species studied. Our study indicated that $500 \mathrm{~g}$ of milk can meet more than $60 \%$ recommended daily allowances of $\mathrm{Ca}$ and $\mathrm{P}$ as recommended by Institute of Medicine, Washington (DC) and National Institute of Nutrition, Hyderabad.
\end{abstract}

Keywords: Alpine x Beetle, Minerals, Murrah, Sahiwal, Tharparkar

\section{Introduction}

Milk has an important place in human diet. It is almost a complete food for human beings having all the essential nutrients including minerals (De La Fuente et al. 2003). Minerals are important for growth, development and regulation of various vital functions in

Dairy Chemistry Division, ICAR-National Dairy Research Institute, Karnal, 132001 India

Rajan Sharma( $₫)$

Dairy Chemistry Division, ICAR-National Dairy Research Institute, Karnal, 132001 India

E-mail: rajansharma21@gmail.com

Phone: +91-9416120181 our body and approximately $4-6 \%$ of human body weight is composed of mineral elements (Saraf \& Samant, 2013). These minerals are also important for building strong bones and teeth, and maintaining the ionic equilibrium of body fluids. Even in trace amounts, these minerals perform innumerable vital body functions. Milk contains more than 20 different minerals such as calcium $(\mathrm{Ca})$, magnesium $(\mathrm{Mg})$, sodium $(\mathrm{Na})$, potassium $(\mathrm{K})$, phosphorus $(\mathrm{P})$, zinc $(\mathrm{Zn})$, iron $(\mathrm{Fe})$, copper $(\mathrm{Cu})$, manganese (Mn) etc. Milk is the most important source of bioavailable $\mathrm{Ca}$ and $\mathrm{P}$ in our diet, $\mathrm{Ca}$ through milk is better retained by the body in comparison to vegetables (De La Fuente et al. 2003). The reported data showed that the mineral contents of the various milk species and breeds varied considerably and their content appeared to be affected by genetic, physical and environmental factors (Raynal-Ljutovac et al. 2008). Although P is an essential nutrient, there is concern that excessive amounts may be detrimental to bone health, especially when accompanied with low Ca intake (Cashman, 2002).

Minerals also play an important role in structure and stability of casein micelles. In milk, most of these macro-elements are distributed differently into diffusible (soluble) and non-diffusible (colloidal) fractions, and the latter form is mainly associated with casein micelles. K, Na and chloride ions are essentially diffusible although $\mathrm{Ca}$, inorganic phosphate and $\mathrm{Mg}$ are partly bound to the casein micelles. About one-third of $\mathrm{Ca}$, half of the inorganic phosphate, two-thirds of $\mathrm{Mg}$ and over $90 \%$ of citrate are in the aqueous phase of bovine milk (Gaucheron, 2005). A small proportion of $\mathrm{Ca}$ is also bound to $\alpha$-lactalbumin as there is one atom of Ca per molecule. Equilibrium exists in the distribution of $\mathrm{Ca}$ and phosphate between soluble and colloidal phases. Colloidal $\mathrm{Ca}$ phosphate (CCP) plays an integral role in maintaining the integrity of the casein micelle and removal of CCP markedly affects heat stability throughout the $\mathrm{pH}$ range $6.6-7.4$, but removal of $60-70 \%$ of CCP increase stability in the $\mathrm{pH}$ range $6.4-7.0$ (Gaucheron, 2005). Atomic absorption spectrophotometer (AAS) is commonly used in many analytical laboratories for estimation of minerals in water and in acid digest of sediment or biological materials. The dry or wet ashing method is commonly used to destroy organic material in milk and milk products before analysis by AAS. Fine mist of digested sample solution is aspirated into the flame at a particular wavelength. The decrease in intensity of 
the radiation from the hollow cathode lamp due to absorption by specific atoms in the flame is measured (Wehr \& Frank, 2004).

In the past, studies have been done mainly focusing on nutritional status of bovine milk, but lesser data are available for mineral content and their distribution in milk of other species. Also the minerals and their distribution in milk from indigenous breeds was not reported. The various food standard regulation authorities are trying to develop standards for mineral content and their distribution in milk. Our research data will help them to developed new standards. In the present study, nine major and trace minerals (Ca, Mg, P, Na, K, Zn, Fe, Cu and Mn) in milk of three different species namely, cow (Sahiwal and Tharparkar), buffalo (Murrah) and goat (Alpine x Beetle) of India have been estimated along with their distribution in colloidal and soluble phase.

\section{Materials and Methods}

\section{Samples and reagents}

Fifteen individual milk samples of cow (Sahiwal and Tharparkar breeds), buffalo (Murrah) and goat (Alpine x Beetle) were collected from apparently healthy animals from Livestock Research Center, ICAR-NDRI, Karnal during winter months. All the milk samples were collected fresh and immediately analyzed at National Referral Center for Milk Quality and Safety, ICARNDRI, Karnal, India. Water with conductance $0.055 \mathrm{mhos} / \mathrm{cm}$ was used for analysis. Nitric acid, hydrochloric acid of analytical grade were procured from Merck KGaA, Dramstadt, Germany. NIST traceable standard solutions for all the elements and lanthanum chloride were purchased from Sigma-Aldrich Inc., St. Louis, USA.

\section{Cleaning of glassware}

All the glassware used for AAS analysis were washed properly and soaked in chromic acid solution for $24 \mathrm{~h}$, rinsed with deionized water, dipped in $3 \%$ EDTA solution for $24 \mathrm{~h}$ and rinsed with deionized water again before use.

\section{Calibration of equipment}

The atomic absorption spectrophotometer was calibrated before every analysis and the dilutions of standard solutions were prepared just before analysis. A blank sample and standard solutions of known concentrations were measured for absorbance.

\section{Total ash contents}

Ash content of all the samples was determined according to AOAC (2016a) using microprocessor controlled muffle furnace (Metrex Scientific Instruments, New Delhi). Ash was prepared by taking $1 \mathrm{~g}$ of milk sample in silica crucible followed by heating on a hot plate to complete charring. The charred samples were incinerated in a muffle furnace at $550^{\circ} \mathrm{C}$ for $3-4 \mathrm{~h}$ till white ash was obtained. The ash was cooled in desiccators, the weight determined, and ash percentage was calculated.

\section{Fractionation procedure}

Fractionation of whole milk between colloidal and soluble phase was done as suggested by Fransson and Lönnerdal (1983) with modification. The method is depicted in Fig 1. Raw milk samples were defatted by centrifugation $\left(4000 \mathrm{~g}, 10 \mathrm{~min}, 4^{\circ} \mathrm{C}\right)$ and skim milk was ultrafiltered with Amicon ${ }^{\circledR}$ Ultra-15, $10 \mathrm{KDa}$ Centrifugal Filter Devices (Merck, Germany) using centrifuge (5000 g, 40 min, $25^{\circ} \mathrm{C}$ ). The retentate was discarded and permeate was analyzed for soluble minerals. The minerals present in permeate of skim milk were considered to represent soluble phase of minerals. The original procedure recommended by Fransson and Lönnerdal (1983) reported the use of ultracentrifugation $(150,000$ $\mathrm{g}$ for $1 \mathrm{~h}$ ) of skim milk to remove majority of the colloidal phase by pelleting of the casein micelles. The supernatant was further subjected to ultra-filtration using $10 \mathrm{KDa}$ membranes. Gaucheron (2005) also recommended the use of ultra-filtration using 10-15 KDa cut-off membrane to distinguish between colloidal and soluble mineral fraction in milk. As $\mathrm{pH}$ and temperature may influence the distribution of minerals in different phases, the experiments in this study were done by avoiding unnecessary delays.

\section{Mineral estimation}

Estimation of minerals in whole milk samples and of permeate (obtained after fractionation) was done by dry digestion method. For this, $10 \mathrm{~g}$ milk sample or permeate/whole milk was charred in a silica crucible and ashed in microprocessor controlled muffle furnace at $550^{\circ} \mathrm{C}$ for $5 \mathrm{~h}$. Major mineral elements such as $\mathrm{Ca}, \mathrm{Mg}$, $\mathrm{Na}$ and $\mathrm{K}$ were quantified using method suggested by International Organization for Standardization (ISO, 2007) and trace minerals such as $\mathrm{Zn}, \mathrm{Fe}, \mathrm{Cu}$ and $\mathrm{Mn}$ were determined by AOAC (2016b) official method using atomic absorption spectrophotometer (Model: AA-7000; Shimadzu, Japan). Phosphorus was estimated spectrophotometrically; absorbance was noted using Elisa Reader (Infinite 200 Pro Nano Quant) at $820 \mathrm{~nm}$ (ISO, 2006). Colloidal mineral content was calculated by subtracting the content of soluble mineral fraction (permeate) from the total mineral content (whole milk).

\section{Statistical analysis}

The concentrations of all the elements were reported as the mean \pm S.D. Data obtained were tested by ANOVA (one-way ANOVA randomized complete blocks). Differences and similarities between the means of mineral contents of different species (in whole milk and soluble fraction of milk) were achieved by using the Duncan Multiple Range test. Each mineral element was analyzed at least three times for each animal. Ash content was reported as mean of six determinations. 
Fig 1. Fractionation procedure for study of distribution of minerals in colloidal and soluble phase in milk

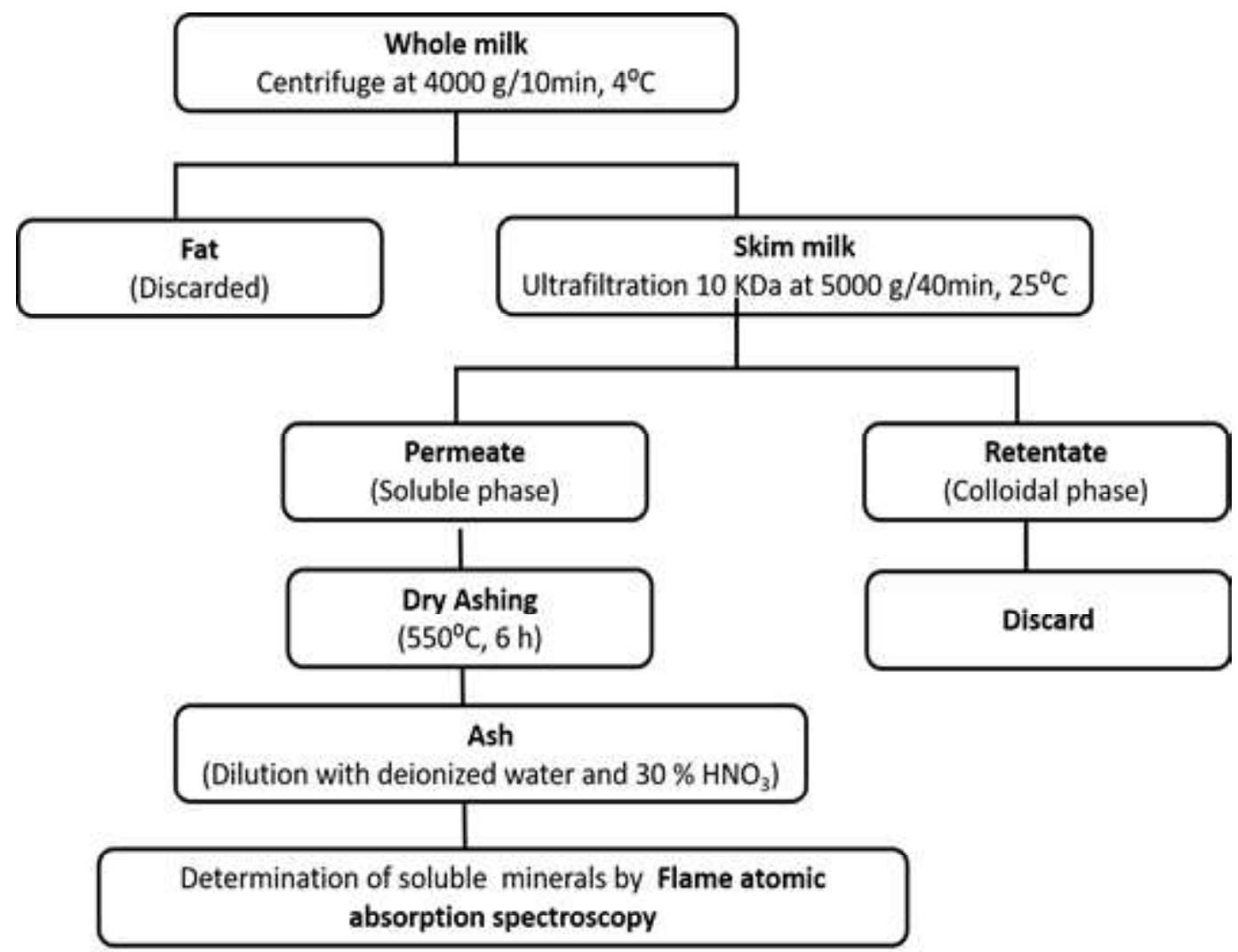

Fransson and Lönnerdal (1983)

\section{Results and Discussion}

Study of major and trace elements makes it possible to define the degree to which a product can meet the human requirements for particular element. There are several studies dealing with the mineral content of milk, but most of them are of foreign origin.

\section{Total mineral content in milk of various species}

The total mineral content in a milk sample is usually assessed by its ash content. The estimated ash content of Tharparkar cow, Sahiwal cow, Murrah buffalo and Goat (Alpine x Beetle) milk was observed to be $0.72 \pm 0.003,0.74 \pm 0.004$, and $0.80 \pm 0.002$ and $0.76 \pm 0.008 \%$, respectively. The ash content was observed significantly high $(\mathrm{p}<0.001)$ in buffalo milk as compared to milk of other species. However, the ash content of cow and goat milk did not differ significantly. The average mineral content from various species and its distribution in soluble phase of milk are presented in Table 1. The results indicated that total content of major minerals such as $\mathrm{Ca}, \mathrm{Mg}$, and $\mathrm{P}$ was found highest in buffalo milk. The content of $\mathrm{Ca}$ in buffalo milk was about 1.5 times higher than cow and goat milk. Similarly, Mg content was found 2 times higher in buffalo milk as compared to cow and goat milk. On the other hand, Na content was found lowest in buffalo milk. Potassium content was observed to be highest in goat milk. Among the two species of cow milk, Sahiwal cow milk was observed to have higher content of $\mathrm{Ca}, \mathrm{Na}, \mathrm{K}, \mathrm{P}$ and $\mathrm{Zn}$ as compared to Tharparkar cow milk (Fig 2). Table 1 also revealed that among the various minerals studied, $\mathrm{K}$ was found as major mineral in cow and goat milk. On the other hand, Ca was found to be as major mineral in buffalo milk. Fe content did not vary in the milk of the species studied.

The total Ca content in Sahiwal cow and Tharparkar cow, buffalo and goat milk was 134.87, 125.43, 204.23 and $135.09 \mathrm{mg} / 100 \mathrm{~g}$, respectively. Ca content was found to be higher in cow (Sahiwal and Tharparkar breeds), buffalo and goat milk as compared to the previously reported levels such as 104-128; 188, 134.5, mg/ $100 \mathrm{~g}$, respectively in cow, buffalo and goat milk. (Gaucheron, 2005; Ahmad et al. 2008; Singh et al. 2015). The total Mg content in Sahiwal cow, Tharparkar cow, buffalo and goat milk was observed to be $10.87,10.24,23.53$ and $10.81 \mathrm{mg} / 100 \mathrm{~g}$, respectively. The observed $\mathrm{Mg}$ content reported in different species showed variation with the reported values given by different researchers. $\mathrm{Mg}$ content in bovine milk was in the range 9.7-14.6 mg/100 g (Gaucheron, 2005); while it was $23 \mathrm{mg} / 100 \mathrm{~g}$ in buffalo milk (Ahmad et al. 2008) and 10-21.7 mg/100 g in goat milk (Ruegg, 2017). Total $P$ content observed in Sahiwal and Tharparkar cow, buffalo and goat milk was $90.24,86.71,117.45$ and $92.06 \mathrm{mg} / 100 \mathrm{~g}$, respectively. The P content in Sahiwal and Tharparkar cow was observed to be lesser than that $(93-99 \mathrm{mg} / 100 \mathrm{~g})$ reported by Gaucheron (2005), whereas higher content $(117 \mathrm{mg} / 100 \mathrm{~g})$ in buffalo milk was 


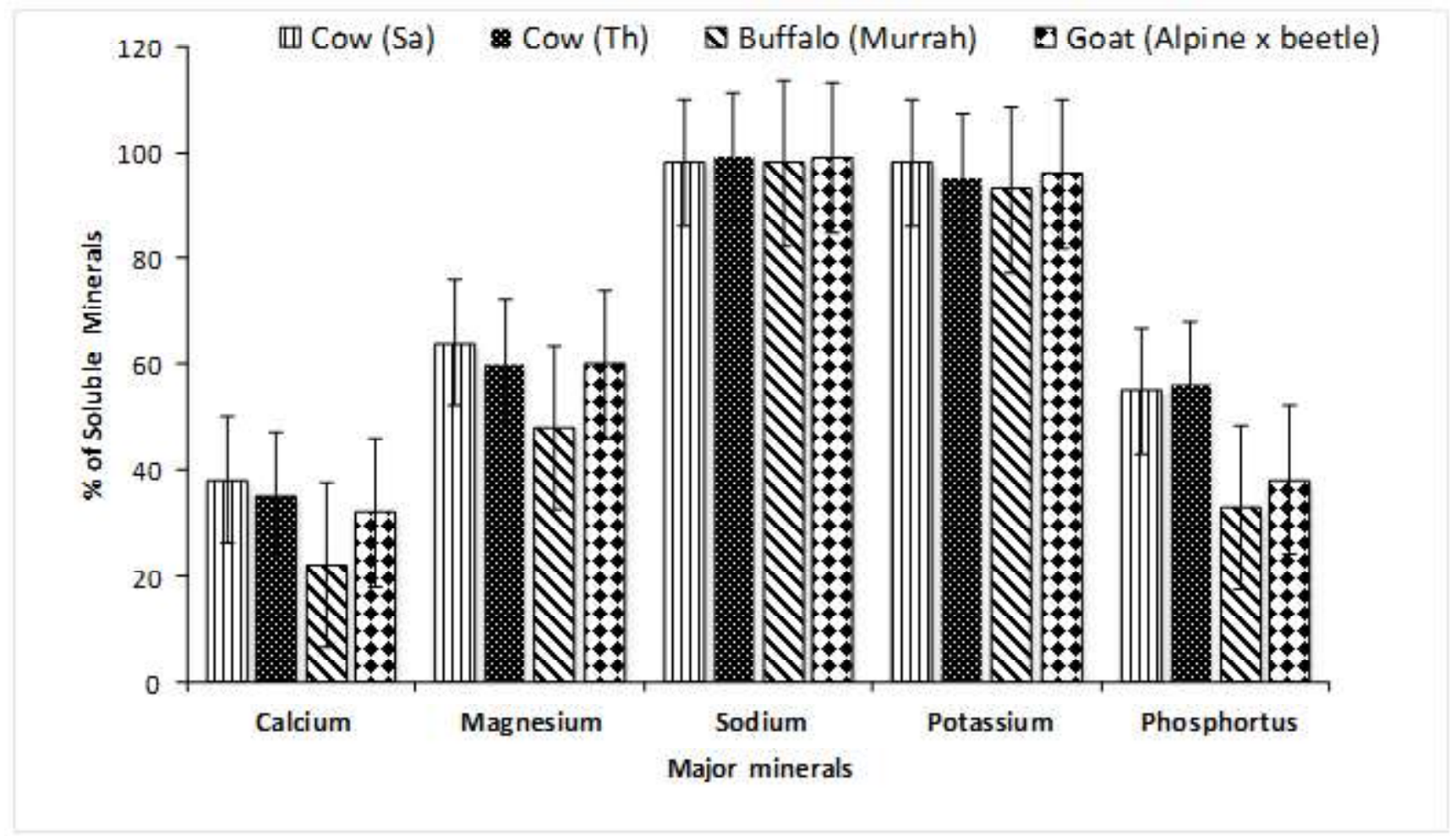

Fig 2. Percentage of soluble major mineral content in milk of various species. Error bars show the variations in terms of standard deviation $(\mathrm{n}=15)$

observed than that $(90 \mathrm{mg} / 100 \mathrm{~g})$ reported by Ahmad et al. (2008). Total K content in Sahiwal and Tharparkar cow was found to be lower $(145 \mathrm{mg} / 100 \mathrm{~g})$ than that $(168 \mathrm{mg} / 100 \mathrm{~g})$ reported by MorenoRojas et al. (1994); it was higher in goat milk $(174.8 \mathrm{mg} / 100 \mathrm{~g})$ than reported (135.5 mg/100 g) by Singh et al. (2015). In cow milk, $\mathrm{Na}$ content was observed to be lower (around $53 \mathrm{mg} / 100 \mathrm{~g}$ ) and was higher in goat milk $(52.89 \mathrm{mg} / 100 \mathrm{~g})$ as reported $(44 \mathrm{mg} / 100$ g) by Moreno-Rojas et al. (1994).

\section{Distribution of minerals (colloidal and soluble fractions) in milk} of various species

\section{Major minerals}

The concentration of major elements present in milk mainly depends on the species, individuality of animal, feed, lactation stage, and health condition of the udder (Cashman, 2006). The major mineral distribution in milk of various species is presented in Table 1. It was noted that $\mathrm{Na}(>98 \%)$ and $\mathrm{K}(>93 \%)$ are almost entirely present in soluble fraction of milk of all the species. In general, the contents of soluble minerals were less in buffalo milk and more in cow milk (Table 1 and Fig 1). Maximum fraction of two major minerals i.e. $\mathrm{Ca}$ and $\mathrm{P}$ was found to be associated with colloidal phase in buffalo and goat milk. More than $60 \%$ of $\mathrm{P}$ was found to be in colloidal phase in buffalo milk $(67 \%)$ and goat milk $(62 \%)$, while in cow milk, major amount $(55 \%)$ was associated with soluble phase. In case of $\mathrm{Mg}$, the maximum content was accompanying with colloidal phase in buffalo milk $(52 \%)$ while in milk of other species it was associated with soluble milk fraction (60-64 \%). Higher content of colloidal $\mathrm{Ca}$ and $\mathrm{P}$ in buffalo milk vis-a-vis other species may be due to inherent high content of casein in buffalo milk; it has been reported by Sindhu and Arora (2011) that except $\alpha_{\mathrm{s} 2}$-casein, all other casein fractions are in higher concentration in buffalo milk, which may be responsible for the higher colloidal content of $\mathrm{Ca}$ and $\mathrm{P}$ in buffalo milk. The soluble fraction of $\mathrm{Ca}$ was found higher in milk of Sahiwal (38\%) and Tharparkar breeds (35\%) than that reported by Gaucheron (2005), in bovine milk (33.5\%). The $\mathrm{Ca}$ and $\mathrm{P}$ (soluble content) in cow milk (38\% and $55 \%$ ) and goat milk ( $32 \%$ and $38 \%$ ) were observed to have a slight variation with findings of previous researchers. Gaucheron (2005) reported soluble $\mathrm{Ca}$ and $\mathrm{P}$ content in cow milk was 33.5 and $43 \%$ and De La Fuente et al. (1997) indicated 34 and $41 \%$. In present study, in buffalo milk, the distribution of $\mathrm{Ca}, \mathrm{P}$ and $\mathrm{Mg}$ in soluble phase was 22,33 and $48 \%$, respectively. These findings are in agreement with earlier reported values by Ahmad et al. (2013) (Ca: 22\%; P: 32\%; and Mg: 50\%).

\section{Trace elements}

Trace metals are normally needed by living organisms to function properly and are depleted through the expenditure of energy by various metabolic processes of living organisms. Of the total 20 essential minerals, 14 are trace elements (Zamberlin et al. 2012). In the present study, the results indicated that the studied trace 
Fig 3. Percentage of soluble trace mineral content $(\%)$ in milk of various species. Error bars show the variations in terms of standard deviation $(n=15) . S a-$ Sahiwal, Th - Tharparkar

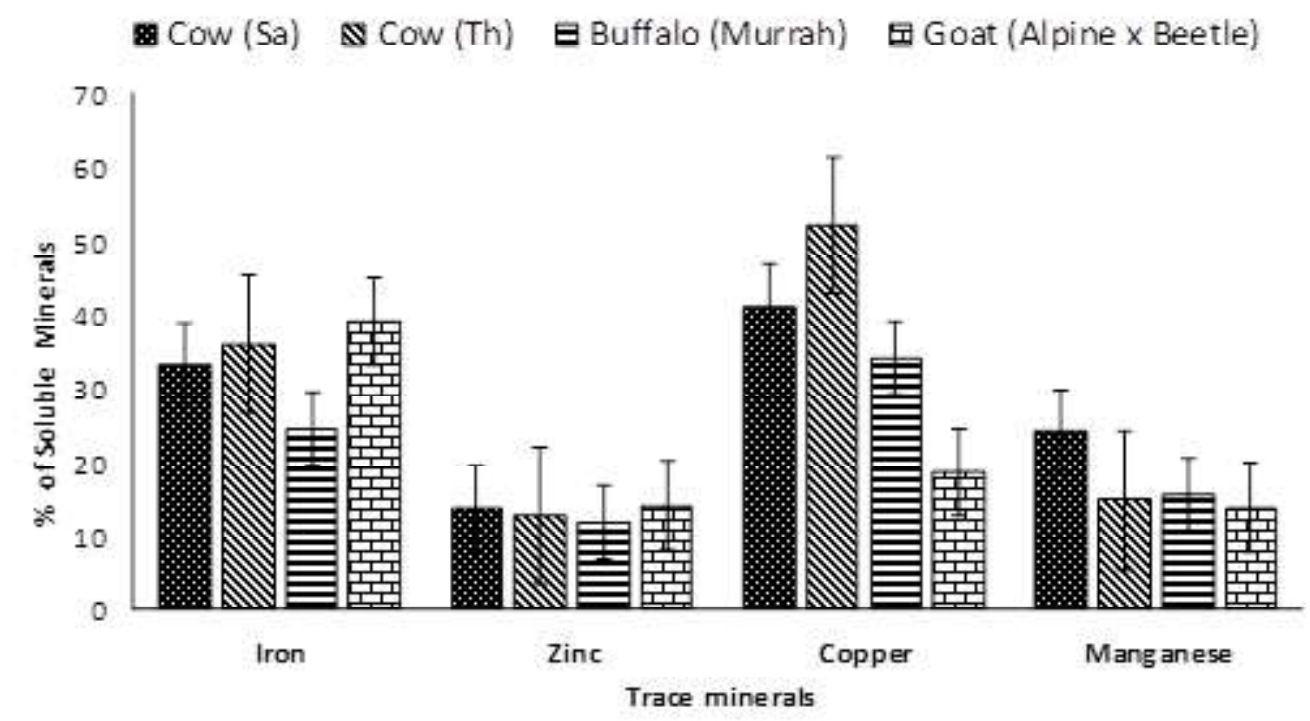

Table 1. Mineral content $(\mathrm{mg} / 100 \mathrm{~g})$ in milk of various species along with soluble fraction of various minerals

\begin{tabular}{|c|c|c|c|c|c|}
\hline \multirow{2}{*}{\multicolumn{2}{|c|}{ Type of element }} & \multicolumn{4}{|c|}{ Type of milk } \\
\hline & & Cow (Sahiwal) & Cow (Tharparkar) & Buffalo (Murrah) & Goat (AlpinexBeetle) \\
\hline \multirow[t]{2}{*}{$\overline{\text { Calcium }}$} & Total & $134.87 \pm 13.45^{\mathrm{c}}$ & $125.43 \pm 8.31^{\mathrm{d}}$ & $204.23 \pm 7.98^{\mathrm{a}}$ & $135.09 \pm 8.52^{\mathrm{b}}$ \\
\hline & Soluble & $51.16 \pm 6.13^{\mathrm{a}}(38 \%)$ & $43.47 \pm 4.45^{\mathrm{c}}(35 \%)$ & $44.91 \pm 4.91^{\mathrm{b}}(22 \%)$ & $43.25 \pm 5.33^{\mathrm{d}}(32 \%)$ \\
\hline \multirow[t]{2}{*}{ Magnesium } & Total & $10.87 \pm 1.31^{\mathrm{b}}$ & $10.24 \pm 1.36^{\mathrm{d}}$ & $23.53 \pm 1.33^{\mathrm{a}}$ & $10.81 \pm 1.3^{\mathrm{c}}$ \\
\hline & Soluble & $6.99 \pm 0.79^{\mathrm{b}}((64 \%)$ & $6.15 \pm 1.14^{\mathrm{d}}(60 \%)$ & $11.33 \pm 0.67^{\mathrm{a}}(48 \%)$ & $6.5 \pm 0.92^{\mathrm{c}}(60 \%)$ \\
\hline Sodium & Total & $54.06 \pm 5.9^{\mathrm{a}}$ & $52.95 \pm 2.42^{\mathrm{b}}$ & $42.39 \pm 0.82^{\mathrm{c}}$ & $52.89 \pm 2.07^{\mathrm{b}}$ \\
\hline & Soluble & $141.88 \pm 6.31^{\mathrm{b}}(98 \%)$ & $134.92 \pm 9.96^{\mathrm{c}}(95 \%)$ & $109.52 \pm 6.91^{\mathrm{d}}(93 \%)$ & $167.33 \pm 5.67^{\mathrm{a}}(96 \%)$ \\
\hline \multirow[t]{2}{*}{ Phosphorus } & Total & $90.24 \pm 1.3^{\mathrm{c}}$ & $86.71 \pm 3.75^{\mathrm{d}}$ & $117.45 \pm 5.26^{\mathrm{a}}$ & $92.06 \pm 2.16^{\mathrm{b}}$ \\
\hline & Soluble & $49.31 \pm 0.76^{\mathrm{a}}(55 \%)$ & $48.59 \pm 2.15^{\mathrm{b}}(56 \%)$ & $38.37 \pm 1.8^{\mathrm{a}}(33 \%)$ & $34.75 \pm 8.65^{\mathrm{c}}(38 \%)$ \\
\hline \multirow[t]{2}{*}{ Zinc } & Total & $0.62 \pm 0.14^{\mathrm{a}}$ & $0.506 \pm 0.066^{\mathrm{b}}$ & $0.51 \pm 0.1^{\mathrm{b}}$ & $0.48 \pm 0.67^{\mathrm{c}}$ \\
\hline & Soluble & $0.085 \pm 0.022^{\mathrm{a}}(14 \%)$ & $0.064 \pm 0.01^{\mathrm{c}}(13 \%)$ & $0.06 \pm 0.017^{c}(12 \%)$ & $0.068 \pm 0.015^{\mathrm{b}}(14 \%)$ \\
\hline & Soluble & $0.029 \pm 0.005^{\mathrm{b}}(41 \%)$ & $0.037 \pm 0.005^{\mathrm{a}}(52 \%)$ & $0.021 \pm 0.019^{\mathrm{c}}(34 \%)$ & $0.0093 \pm 0.001^{\mathrm{d}}(18 \%)$ \\
\hline \multirow[t]{2}{*}{ Manganese } & Total & $0.036 \pm 0.008^{\mathrm{b}}$ & $0.06 \pm 0.01^{\mathrm{a}}$ & $0.05 \pm 0.018^{\mathrm{a}}$ & $0.03 \pm 0.012^{b}$ \\
\hline & Soluble & $0.0085 \pm 0.006^{\mathrm{b}}(23 \%)$ & $0.0088 \pm 0.01^{\mathrm{a}}(14 \%)$ & $0.0078 \pm 0.014^{\mathrm{c}}(15 \%)$ & $0.0041 \pm 0.002^{\mathrm{d}}(14 \%)$ \\
\hline \multicolumn{2}{|l|}{$\mathrm{Ca} / \mathrm{P}$ ratio } & 1.49 & 1.45 & 1.74 & 1.47 \\
\hline
\end{tabular}

Mean $\pm \operatorname{SD}(n=15)$

Statistical analysis (total milk) by one-way Anova Randomized Complete Block Design using Duncan's multiple Range Test. Data with the same superscript along the same row are not significantly different at $\mathrm{p} \leq 0.05$.

minerals ( $\mathrm{Zn}, \mathrm{Fe}, \mathrm{Cu}$ and $\mathrm{Mn}$ ) were associated with colloidal phase in milk of all the species (Fig 3). Among these minerals, $\mathrm{Cu}$ was observed to have the highest solubility in cow (41-52\%) and buffalo milk (34\%). Goat milk was an exception with very low content of $\mathrm{Cu}$ in soluble phase (18\%). In buffalo milk $75 \%$ of Fe was observed to be associated with colloidal phase, while in milk of other species, around $64 \%$ of Fe was in colloidal phase. In milk of all the species, majority of the $\mathrm{Zn}(>86 \%)$ content was observed to be associated with colloidal phase. Copper content was observed higher in goat milk $(0.05 \mathrm{mg} / 100 \mathrm{~g})$ than the previously reported value $(<0.025 \mathrm{mg} / 100 \mathrm{~g})$ by Singh et al. (2015), while the Fe content $(0.078 \mathrm{mg} / 100 \mathrm{~g})$ was found lower than that $(0.097 \mathrm{mg} /$ $100 \mathrm{~g}$ ) reported by Singh et al. (2015). The soluble fraction of $\mathrm{Cu}$ was observed to be lowest in goat milk. The $\beta$ - casein is the most 
Table 2. Contribution to daily dietary intake of minerals by milk of various species ( $500 \mathrm{~g})$

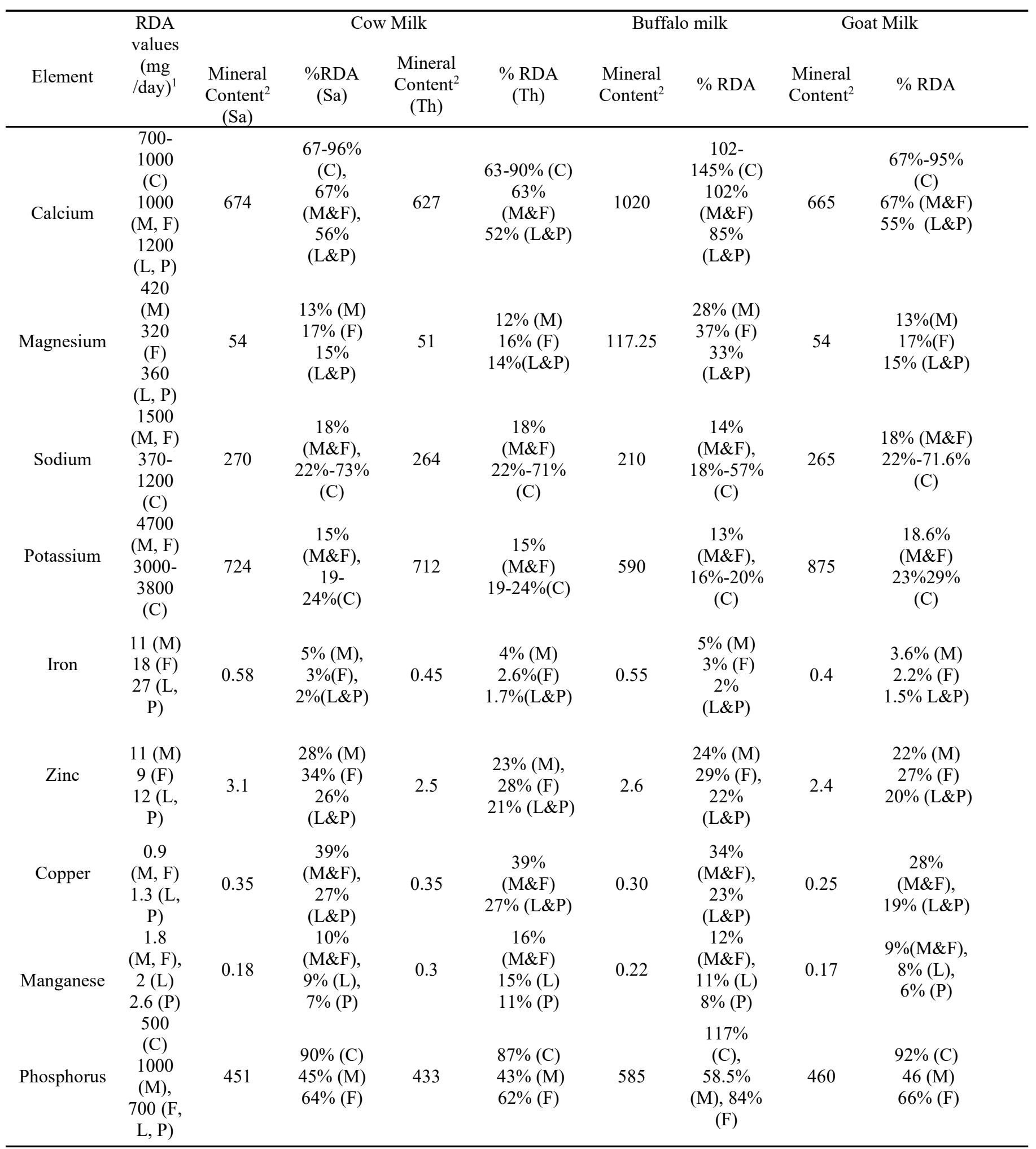

${ }^{1}$ as suggested by Institute of Medicine, 2011 and NIN, 2018; ${ }^{2}$ content in mg per $500 \mathrm{~g}$ milk

C- Children, M-Male, F-Female, L-Lactating \& P-Pregnant; Sa - Sahiwal, Th - Tharparkar 
abundant protein found in goat micelles; it influences the retention of $\mathrm{Cu}$ in the colloidal phase, which causes a decrease in solubility of $\mathrm{Cu}$ (Storry et al. 1983). The chemical form of major and trace minerals found in milk or in other foods / supplements is important because it influences the degree of intestinal absorption, utilization, transport, cellular assimilation and conversion into biologically active forms and thus their bioavailability (Cashman, 2006). The distribution study indicated that Sahiwal breed contains highest fraction of soluble major minerals, whereas buffalo milk is characterized by high Ca content in colloidal phase. Thus, the milk products prepared by separation of curd and whey (e.g. cheese, paneer) from buffalo milk will contain more $\mathrm{Ca}$ and other colloidal minerals vis-à-vis, such products prepared from cow / goat milk as more minerals are lost in whey fraction (Goyal and Gandhi, 2009).

\section{Contributions to RDA of minerals by milk of various indigenous species per $500 \mathrm{~g}$}

Institute of Medicine (2011) has recommended critical values for these elements called Recommended Daily Allowance (RDA). Table 2 depicts the variation in mineral contributions by milk ( 500 g) of various species. It is worth mentioned here that RDA values for Indians as recommended by National Institute of Nutrition (NIN, 2018) are almost similar as that of recommended by Institute of Medicine, Washington.

Calcium is the most important mineral in milk, which is essential for tissue, bone and teeth development. Adequate intake of $\mathrm{Ca}$ is required for maintaining bone health and to reduce risk of osteoporosis. Ca is also known to be anti-carcinogenic (Shin et al. 2002). About $98 \%$ of the total Ca present in our body is found in bones and teeth (Latham, 1997). Milk and milk products are known to be very rich source of $\mathrm{Ca}$.

Phosphorus is the second most abundant mineral element found in human body after $\mathrm{Ca}$. About $80 \%$ of phosphorus is combined with $\mathrm{Ca}$ in bones and teeth whereas $20 \%$ participates in body functions like cell growth and contraction of heart muscle (Passmore \& Eastwood, 1986). It is also an important component of adenosine triphosphate (ATP), phospholipids and nucleic acids (Peeley, 1998). On comparing contribution to daily dietary intake of minerals by milk of different species, $\mathrm{Ca}$ and $\mathrm{P}$ contribution to RDA was maximum by buffalo milk. Five hundred grams of buffalo milk is sufficient to meet the daily requirement of $\mathrm{RDA}$ of $\mathrm{Ca}$ and $\mathrm{P}$ for people of all ages including children. The present study indicated highest $\mathrm{Ca}: \mathrm{P}$ ratio in buffalo milk. As Ca phosphate, $\mathrm{P}$ is the most important structural component of bones and teeth but excessive intake of $\mathrm{P}$ combined with reduced $\mathrm{Ca}$ intake may have negative effects on bones (Cashman, 2002). Higher intake of Ca also decreases absorption of $\mathrm{P}$ in the intestine (Nolan \& Qunibi, 2003). There must exist an appropriate $\mathrm{Ca}: \mathrm{P}$ ratio in human diet to ensure optimal bone health. Based on calculation of recommended dietary $\mathrm{Ca}$ and $\mathrm{P}$ intakes, the optimal dietary $\mathrm{Ca}: \mathrm{P}$ ratio (Infants, Children, Adults and Lactating Mothers) varies from 1-2. RDA of $\mathrm{Ca}: \mathrm{P}$ is 1-1.72 for people of all age groups (Institute of Medicine, 2011). Excessive dietary P intake alone can be deleterious to bone through increased parathyroid hormone $(\mathrm{PTH})$ secretion, and adverse effects on bone increase when dietary intake is low. Low $\mathrm{Ca}$ :P ratio affects $\mathrm{Ca}$ metabolism and leads to bone loss and osteopenia while high $\mathrm{Ca}: \mathrm{P}$ ratio is good for bone health. Milk and milk products are rich source of $\mathrm{P}$ and $\mathrm{Ca}$ as required for adequate $\mathrm{Ca}: \mathrm{P}$ ratio, and meet the recommended $\mathrm{Ca}: \mathrm{P}$ ratio (Kemi et al. 2010).

Magnesium is primarily an intercellular mineral. About $50-60 \%$ of the total magnesium found in our body is found in bones together with Ca and P (Rude \& Gruber, 2004). This mineral element plays diverse roles in protein and carbohydrate metabolism and synthesis of DNA. It forms a complex with ATP (Mg-ATP), which serves as the true substrate for biochemical reactions involving energy utilization (Stryer, 2000). It activates and regulates about 100 enzymes and more than 300 enzymatic reactions in our body. Many of these reactions are directly related to cardiovascular health and help in nerve and muscle function. $\mathrm{Mg}$ is required for insulin activity and is therefore important for prevention of type 2 diabetes (Nielsen, 2010). Mg content in $500 \mathrm{~g}$ cow milk, goat milk and buffalo milk is 51, 54 and $117 \mathrm{mg}$, respectively. Buffalo milk can contribution remarkable RDA for $\mathrm{Mg}$ especially in children.

Sodium is the main cation involved in the extracellular fluid. This mineral element is known to be associated with regulation of nerve and muscle function, plasma volume regulation and acidbase balance (Anderson et al. 2004). Cow and goat milk contribute maximum towards RDA of Na.

Potassium plays an important role in the regulation of osmotic pressure, blood pressure, acid-base balance, heartbeat regulation and enzyme activation (Yellen, 2002). Milk of all the species contributes substantially to RDA for $\mathrm{K}$ in adults and children. But the contribution of goat milk is maximum towards RDA of K.

Zinc is a trace element required in the human body for weight gain and height (Brown \& Wuehler, 2000). Zn deficiency causes impaired immune functions and increased propensity to infections (Black, 2003). About 20\% of the world population is at risk of inadequate $\mathrm{Zn}$ intake (IZINCG, 2004) due to poor bioavailability of $\mathrm{Zn}$ from many staple foods. $\mathrm{Zn}$ is also an important component of hormone insulin. It is part of more than 200 enzymes involved in digestion, metabolism, protein synthesis, reproduction and wound healing (Salgueiro et al. 2002). Milk and milk products are very important in human nutrition, but an insufficient source of Zn (Cashman, 2006). RDA of Zn was maximum contributed by cow milk followed by buffalo milk.

Iron in the human body plays important part in hematopoiesis, control of infection and cell mediated immunity (Bhaskaram, 2001). 
$\mathrm{Fe}$ is an important component of hemoglobin in blood, required for oxygen transportation and enzyme systems, vital for formation and functioning of red blood corpuscles and for the functioning of the brain (WHO, 1996). It is essential for several oxidation reactions (Achanta et al. 2007) but unfortunately milk of all the species proved to be poor source of $\mathrm{Fe}$; its contribution to RDA is very low. Contribution of $500 \mathrm{~g}$ grams of milk of any of the species to RDA is only between $2-5 \%$ for adults.

Copper is the third most abundant trace element found in the human body after $\mathrm{Zn}$ and $\mathrm{Fe}$. The total amount of $\mathrm{Cu}$ present in an adult is between $80-150 \mathrm{mg}$ (Alla \& Abdalla, 2012). This trace element is required for the proper functioning of many enzymes including cytochrome $\mathrm{C}$ oxidase for energy production, superoxide dismutase for antioxidant protection, tyrosinase for pigment formation, Lysl oxidase for collagen and elastin formation and clotting factor $\mathrm{v}$ for blood clotting (Sarkar et al. 1994). It is not abundant in milk. In this study, the amount of Cu per $500 \mathrm{~g}$ of cow, buffalo and goat milk was found to be $0.34,0.30$ and $0.28 \mathrm{mg}$, respectively. Cow milk contributes maximum (38\%) to $\mathrm{RDA}$ of $\mathrm{Cu}$ for adults.

Manganese plays significant role in human body by activating certain enzymes such as pyruvate carboxylase, phosphoenol pyruvate carboxykinase glycosyl transferase and the mitochondrial superoxide dismutase (Keen et al. 2004). It also plays an important role in reproductive hormone production, urea excretion and immunity (WHO, 1996). Mn is contributed to a higher extent by buffalo milk as compared to milk of other species.

\section{Conclusions}

Assured information regarding mineral element concentration in milk is essential for society from nutritional and technological point of view. In this study, different concentrations of mineral elements in total as well as the soluble fraction of milk were determined. Out of all the milk samples, buffalo (Murrah) milk provides highest mineral content except $\mathrm{K}$ which is highest in goat milk. This confirms that buffalo milk is the richest source of essential minerals in comparison to milk of other species. Cow milk showed a maximum soluble fraction of essential minerals necessary for the body. Marked increase in levels of soluble mineral content in cow milk could favor the absorption of these minerals in gastrointestinal tract. Results obtained in the present study demonstrate the positive contribution of the mineral elements present in milk of different species to RDA, especially from buffalo milk.

\section{Acknowledgements}

The authors acknowledge the contribution of Director, ICARNDRI, Karnal, for the financial support and providing a necessary facility for carrying out this study.

\section{References}

Achanta K, Aryana KJ, Boeneke CA (2007) Fat free plain set yogurts fortified with various minerals. LWT - Food Sci Technol 40(3): 424-429

Ahmad S, Rousseau F, Grongnet JF, Gaucheron F (2008) Physico-chemical characteristics of casein micelles from buffalo milk in different ionic environments: A comparison with cow milk. Milchwissenschaft 63: 390-393

Ahmad S, Anjum FM, Huma N, Sameen A. Zahoor T (2013) Composition and physico-chemical characteristics of buffalo milk with particular emphasis on lipids, proteins, minerals, enzymes and vitamins. J Anim Plant Sci 23: 62-74

Alla MD, Abdalla EE (2012) Serum copper in Khartoum: A comparison of children and elderly subjects with healthy adults. Khartoum Med J 1: 107-111

Anderson CM, Grenade DS, Boll M, Foltz M, Wake KA, Kennedy DJ (2004). $\mathrm{H}+/$ amino acid transporter 1 (PAT1) is the imino acid carrier: an intestinal nutrient/drug transporter in human and rat. Gastroenterology 127: 1410-1422

AOAC (2016a) Ash of milk. Official Method 945.46. AOAC Official Methods of Analysis. 20 ${ }^{\text {th }}$ Edition AOAC International, Rockville, MD, USA

AOAC (2016b) Lead, cadmium, zinc, copper and iron in foods, atomic absorption s after dry ashing. Official Method 999.10. AOAC Official Methods of Analysis. 20 $0^{\text {th }}$ Edition AOAC International, Rockville, MD, USA

Bhaskaram P (2001) Immunobiology of mild micronutrient deficiencies. $\mathrm{Br}$ J Nutr 85: 75-80

Black RE (2003) Zinc deficiency, infectious disease and mortality in the developing world. J Nutr 133:1485-1489

Brown KH, Wuehler (2000) Zinc and human health: results of recent trial and implication for programme invention and research, Ottawa, The Micronutrient Initiative 1-68. International Development Research Center, Ottawa, Canada

Cashman KD (2002) Calcium intake, calcium bioavailability and bone health. Br J Nutr 87: 169-177

Cashman KD (2006) Milk minerals (including trace elements) and bone health. Int Dairy J 16: 1389-1398

De La Fuente MA, Montes F, Guerrero G, Juarez M (2003) Total and soluble contents of calcium, magnesium, phosphorus and zinc in yoghurts. Food Chem 80: 573-578

De La Fuente MA, Olano A, Juarez M (1997) Distribution of calcium, magnesium, phosphorus, zinc, manganese, copper and iron between the soluble and colloidal phases of ewe's and goat's milk. Le Lait 77: $515-520$

Fransson GB, Lönnerdal BO (1983) Distribution of trace elements and minerals in human and cow's milk. Pediatr Res 17: 912-915

Gaucheron F (2005) The minerals of milk. Reprod Nutr Dev 45: 473-483

Goyal N, Gandhi DN (2009) Comparative analysis of Indian paneer and cheese whey for electrolyte whey drink. World J Dairy Food Sci 4: $70-72$

Institute of Medicine (2011) Committee on the Robert Wood Johnson Foundation Initiative on the Future of Nursing, at the Institute of Medicine. Washington (DC): National Academies Press, USA

International Zinc Nutrition Consultative Group (IZiNCG. (2004) International Zinc Nutrition Consultative Group (IZiNCG) technical document\# 1. Assessment of the risk of zinc deficiency in populations and options for its control. Food Nutr Bull 25: 99-203

ISO 8070:2007 (IDF 119:2007) Milk and milk products - Determination of calcium, sodium, potassium and magnesium contents - Atomic absorption spectrometric method. International Organization of Standardization, Geneva, Switzerland 
ISO 9874:2006 (IDF 42:2006). Milk-Determination of total phosphorus content-Method using molecular absorption spectrometry. International Organization of Standardization, Geneva, Switzerland

Keen CL, Uriu-Adams JY, Ensunsa JL, Gershwin ME (2004) Trace elements /minerals and immunity. In Handbook of Nutrition and Immunology, Humana Press 117-140

Kemi VE, Kärkkäinen MU, Rita HJ, Laaksonen MM, Outila TA, LambergAllardt CJ (2010) Low calcium:phosphorus ratio in habitual diets affects serum parathyroid hormone concentration and calcium metabolism in healthy women with adequate calcium intake. Br J Nutr 103: 561-568

Latham MC (1997) Human nutrition in the developing world. FAO Foods and Nutr Ser. No. 29. Rome

Moreno-Rojas R, Zurera-Cosano G, Amaro-Lopez M A (1994) Concentration and seasonal variation of calcium, magnesium, sodium and potassium in raw cow, ewe and goat milk. Int J Food Sci Nutr 45: 99- 105

Nielsen FH (2010) Magnesium, inflammation, and obesity in chronic disease. Nutr Rev 68: 333-340

NIN (2018) Dietary guidelines for Indian - A manual. Natation Institute of Nutrition, Hyderabad, India

Nolan CR, Qunibi WY (2003) Calcium salts in the treatment of hyperphosphatemia in hemodialysis patients. Curr Opin Nephrol Hypertens 12: 373-379

Passmore R, Eastwood MA (1986) Human Nutrition and Dietetics. $8^{\text {th }}$ edition., Churchill Livingstone, UK

Peeley RM (1998) Major mineral element in dairy products. J Am Diet Assoc 61: 505-510

Raynal-Ljutovac K, Lagriffoul G, Paccard P, Guillet I, Chilliard Y (2008) Composition of goat and sheep milk products: An update. Small Rumin Res 79: 57-72

Rude RK, Gruber HE (2004) Magnesium deficiency and osteoporosis: animal and human observations. J Nutr Biochem 15: 710-716

Ruegg PL (2017) A 100-Year Review: Mastitis detection, management, and prevention. J Dairy Sci 100: 10381-10397
Salgueiro MJ, Zubillaga MB, Lysionek AE, Caro RA, Weill R, Boccio JR (2002) The role of zinc in the growth and development of children. Nutr 18: 510-519

Saraf A, Samant A (2013) Evaluation of some minerals and trace elements in Achyranthes aspera Linn. Int J Pharm Sci 3: 229-233

Sarkar P K, Tamang J P (1994) The influence of process variables and inoculum composition on the sensory quality of kinema. Food Microbiol 11: 317-325.

Shin MH, Holmes MD, Hankinson SE, Wu K, Colditz GA, Willett WC (2002) Intake of dairy products, $\mathrm{Ca}$, and vitamin $\mathrm{D}$ and risk of breast cancer. J Natl Cancer Inst 94: 1301-1310

Sindhu JS, Arora S (2011) Buffalo milk. Encyclopedia of Dairy Sciences (Eds. Fuquay JW, Fox PF, McSweeney, PLH), 2nd edition. 503-51. Academic Press, New York

Singh M, Yadav P, Garg VK, Sharma A, Singh B, Sharma H (2015) Quantification of minerals and trace elements in raw caprine milk using flame atomic absorption spectrophotometry and flame photometry. J Food Sci Technol 52: 5299-5304

Storry JE, Grandison AS, Millard D, Owen AJ, Ford GD (1983) Chemical composition and coagulating properties of renneted milks from different breeds and species of ruminant. J Dairy Res 50: 215-229

Stryer L (2000) Biochemistry 4th edition. W.H. Freeman and co. New York.

Wehr HM, Frank JF (2004) Standard methods for the examination of dairy products. 17th edition. American Public Health Association

WHO (1996) Trace Elements in Human Nutrition and Health, World Health Organization. Geneva, Switzerland

Yellen G (2002) The voltage gated potassium channels and their relatives. Nature 4: $35-42$

Zamberlin S, Antuna, N, Havranek J, Samarzija D (2012) Mineral elements in milk and dairy products. Mljekarstvo 62: 111-125 